\title{
Prototropic molecular-zwitterionic tautomerism of xanthine and hypoxanthine: unexpected biological view
}

\author{
I. V. Kondratyuk, S. P. Samijlenko, I. M. Kolomiets , A. L. Potyahaylo, D. M. Hovorun \\ Institute of Molecular Biology and Genetics, Ukrainian National Academy of Sciences \\ 150 , vul. Zabolotnoho, Kyiv 03143 . Ukraine
} The prototropic molecular-zwitterionic tautomerism of xanthine and hypoxanthine has been investigated by
the semi-empirical quantum-chemical AMI method. Geometric, energetic and other physico-chemical
features of their complete molecular-zwitterionic families of tautomers have been established. The influence
of the environment with universal solvatation mechanism on the tautomeric equilibrium has been evaluated
at Onzager approximation. The comparison of the calculations with the 'H NMR data favours the N7H
Xan and the N9H Hyp tautomers in DMSO solutions. A possible biochemical role of tautomeric (especially
zwitterionic) forms of Xan and Hyp is discussed. The stabilizing influences of both environment and
specific interactions with proteins on rare tautomeric forms are considered. The biological significance of
high energy tautomers is discussed.

Introduction. Biological role of xanthine (Xan), hypoxanthine (Hyp) and their nucleosides xanthosine $(\mathrm{X})$ and inosine (I) is well-known. They can arise as intermediates of nucleic acid degradation, Нyp and Xan being the products of the adenine and guanine (accordingly) deamination, that could cause a mutagenic effect $[1,2]$. The oxidation of Hyp results in Xan as well. Besides, Hyp is a substrate of metalloenzyme xanthine oxidase. At the same time they can play the role of precursors of the canonical purine bases. Anticodon triplets of some tRNAs include Hyp as a minor base [3].

These bases are also of interest for their pharmacological activities. Methyl derivatives of Xan (caffeine, theobromine, theophylline) are widely used due to their hypotensive and spasmolytic effects. Inosine was found to have various therapeutic effects as a component of drug complexes (see e. g. [4] and references therein). There is an information on its anti-HTLV activity [5].

The literature on investigations of these two minor purine bases is not so rich as compared to the

(C) I. V. KONDRATYUK, S. P. SAMULENKo, I. M. KOLOMIETS. A. L. Potyahaylo, D. M. HOVORUN, 2000 canonical purine nucleotide bases adenine, guanine and their parent compound purine [6-17]. Tautomerism and ionization of Xan and its derivatives were studied by UV spectroscopy $[18,19]$ and NMR [19]. The crystal salt of Xan was proved by X-ray diffraction $[20]$ to be the $\mathrm{N} 9 \mathrm{H}$ tautomer. Quite recently four $\mathrm{N} 7 \mathrm{H}$ and $\mathrm{N} 9 \mathrm{H}$ tautomers of Xan were studied by the $a b$ initio LCAO-MO method at high order approximations [21].

Ionization states of Hyp in solution were investigated by UV spectroscopy [22]. First ionization potentials of gas phase Hyp was estimated experimentally [23]. Conformations of crystal deoxyinosine (dI) were studied by X-ray spectroscopy $[24,25]$. Some tautomers of Hyp isolated in a low-temperature matrix were detected by IR spectroscopy [26].

NMR spectroscopy was applied to the study of I and its complex inosiplex [4]. The analogs of yeast alanyl tRNA, in anticodon loop of which inosine was substituted by guanine and adenine, were synthesized to elucidate its biological function $[27]$.

The interactions of Xan, Hyp and a number of their methyl and glycosyl derivatives with ionized and neutral amino acid carboxylic groups were investigated in anhydrous dimethylsulfoxide (DMSO) by IR, UV and NMR spectroscopies [28, 29$]$. 
The energetic stability, structural and electronic properties of all ketonic and enolic tautomers of Hyp were studied at the level of DF'T with BP functional and the DZVP bases set [30]. Energetical stabilities of seven ketonic and enolic molecular tautomers of Hyp were calculated by ab initio method at the MP2 $(6-31+G(d, p))$ and DFT (B3LYP 6-31+G(d, p)) levels of the theory [31].

However, the prototropic tautomerism of Xan and Hyp, unlike the canonical bases, is insufficiently studicd. Particularly, there is a lack of comprehensive information on energetics stability, geometric and electronic structures of $X$ an and Hyp, and their molecular and zwitterionic tautomers. Inasmuch as Xan, Hyp and their derivatives were shown to form often the proton transfer complexes [32], we suggest that their prototropic tautomers could include zwitterionic ones, which may be of great importance in biochemical reactions.

To fill the gap, in this work the complete families of molecular-zwitterionic tautomers of Xan and Hyp were investigated by the semi-empirical quantumchemical AM1 method and the environmental effects (specific and nonspecific) on tautomeric equilibrium were evaluated.

Experimental. Methods. The qualitative stereochemical analysis shows that complete molecularzwitterionic tautomeric family of Xan, the sources being three mobile (acidic) imino protons and six basic centers - acceptors of proton (two carbonyl groups and four endocyclic nitrogen atoms), comprises 53 possible structural isomers -45 molecular and 8 zwitterionic ones.

The complete molecular-zwitterionic family of Hyp tautomers, which is generated by three mobile (acidic) protons and five proton acceptor atoms (one exocyclic oxygen and four endocyclic nitrogens), consists of 12 molecular and 2 zwitterionic tautomers. The topological properties of multidimensional surface of potential energy for each of 53 possible tautomers of Xan and of 14 tautomeric forms of Hyp were studied by AM1 method, which is the most proper one among semi-cmpirical quantum-chemical methods for tasks and objects of this kind.

The calculations were performed in a wide range of initial geometries, which were formed by various disturbances of primarily optimized tautomeric structures with full optimization of all the structural parameters at gradient norm below 0.01 .

The room temperature concentrations of isolated tautomers of Xan and Hyp were evaluated according to Boltzmann distribution.

${ }^{1} \mathrm{H}$ NMR spectra were obtained on a Gemini-200 spectrometer (Varian) in $5 \mathrm{~mm}$ tubes; the chemical shifts of proton resonances are presented in parts per million (ppm) against TMS as internal standard.

Materials. We used xanthine (Xan), 3-methyl xanthine $\left(\mathrm{m}^{3} \mathrm{Xan}\right), 9$-methyl xanthine ( $\left.\mathrm{m}^{9} \mathrm{Xan}\right)$, and hypoxanthine (Hyp) from «Fluka» (GFR); 2'-deoxyinosine (dI) and deuterated dimethylsulfoxide (DMSO-d $d_{6}$ ) from «Aldrich» (USA); tetramethylsilane (TMS) from «Merck» (GFR). DMSO-d ${ }_{0}$ was dried over the $4 \AA$ and $5 \AA$ «Serva» (USA) molecular sieves.

Results and Discussion. Xanthine. The molecular-zwitterionic family of Xan tautomers, covering the range of relative energies about $43 \mathrm{kcal} / \mathrm{mol}$, includes 32 structural isomers -24 molecular and 8 zwitterionic ones (fig. 1 and tables $1-4$ ). The rest of 53 possible isomers are plane symmetrical transitional states of hydroxylic group rotation of some enolic tautomers which correspond to saddle points on the multidimensional surface of potential energy. The most molecular-zwitterionic tautomers of Xan, with exceptions of the XVIII and XX molecular tautomers (symmetry $C_{1}$ ) and their XIX and XXI enantiomers respectively, are planar symmetrical dipole-stable structures (symmetry $\mathrm{C}_{s}$ ). At that the atom deviations from planarity are far smaller than amplitudes of vibrations. In the case of non-planar tautomers and their enantiomers there are significant atom deviations from planarity. So, e. g. for enantiomeric pairs of tautomers XVIII, XIX and XX, XXI dihedral angles $|\mathrm{C} 6 \mathrm{C} 5 \mathrm{~N} 7 \mathrm{H}|$ are $53,5^{\circ}$ and $30,3^{\circ}$ respectively. Non-planarity of the XVIII-XXI molecular tautomers is probably determined by steric factor, in particular, the repulsion between adjacent hydrogen atoms, one of which is hydroxyl one.

As it could be seen from the table 1, the Xan molecular tautomers in free state occupy the range of relative energies about $33 \mathrm{kcal} / \mathrm{mol}$, their dipole moments are within the limits from 1.03 (IX) up to 9.36 D (XXII) and the first potentials of ionization change from $8.91(X X, X X I)$ up to $9.34 \mathrm{eV}$ (I). The all tautomers-zwitterions except the main tautomerzwitterion XXVI are the structures with higher energy compared to molecular tautomers and they occupy the range of relative energies about $25 \mathrm{kcal} / \mathrm{mol}$, having much greater dipole moments within the limits from 9.36 (XXVII) up to 14.81 D (XXXII) and slightly smaller ionization potentials, which change from 8.36 (XXXI) up to $9.03 \mathrm{eV}$ (XXXII) (table l). It should be noted that tautomer-enantiomers (their numbers are given via commas in table 1) have the identical scalar physical and chemical characteristics and differ only in spatial orientations of dipole moments.

The X, XI, XIII, XIV, XX, XXI, XXIII molecular tautomers and the XXVIII and XXX zwitterion-tautomers are the high energy rotamers of the 


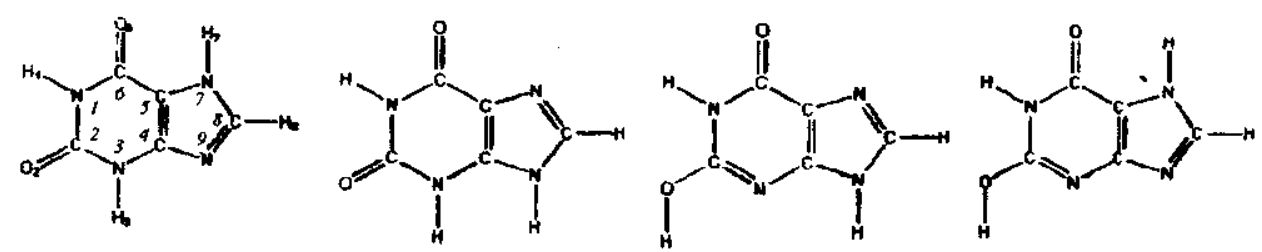

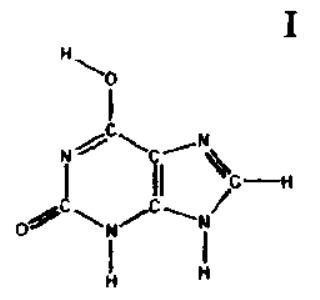<smiles>CCCCC[AlH]</smiles>

II

III

IV

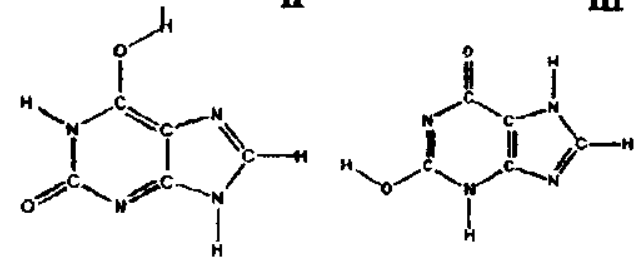<smiles>CCC1CC2=C(CC(C)C(C)C2)C(CC)C1</smiles><smiles></smiles><smiles>[AlH2]</smiles>

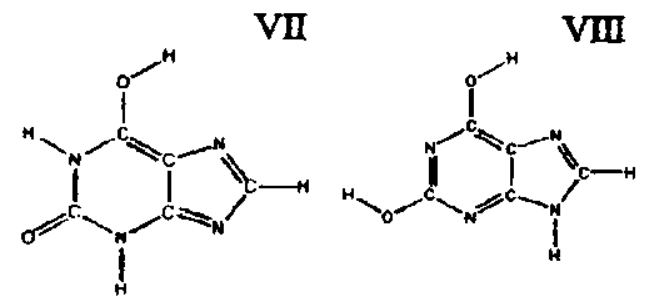<smiles>[Y]Cc1cnc2c(n1)C(C)C(C)N2</smiles>

IX<smiles></smiles>

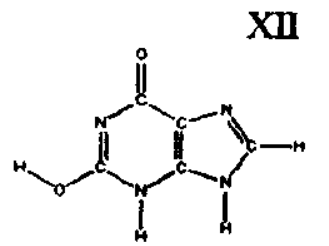

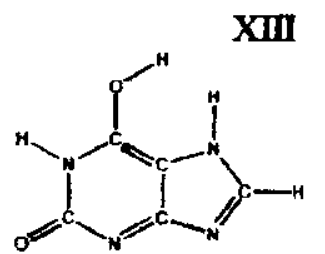<smiles>[W]#[W]</smiles>
XIV

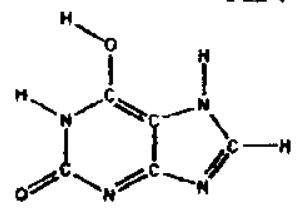<smiles></smiles><smiles></smiles>

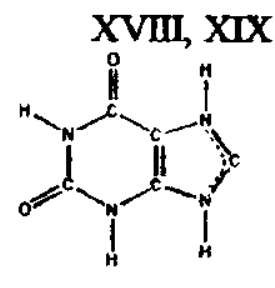

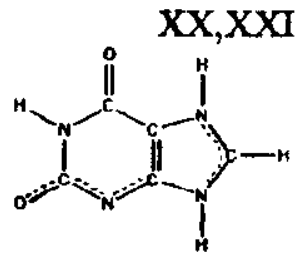

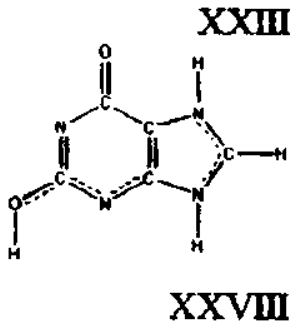<smiles>[R]C([R])=O</smiles>

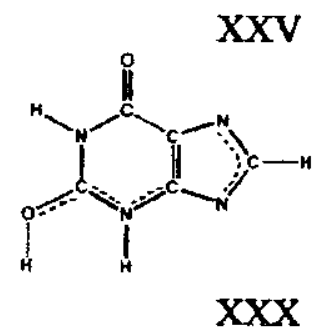<smiles>[R]C1=C(C)C(C)=C2C(OC)=CC(=O)C=C12</smiles>

Fig 1. Schemes of xanthine molecular and zwitterionic tautomers 
<smiles>Cc1nc2c(nc(C)n2C)c(=O)n1C</smiles><smiles>IOc1ncnc2nc[nH]c12</smiles>

V<smiles>[2H]c1nc2[nH]cnc(O)c-2n1</smiles>

$\mathbf{L X}$<smiles></smiles><smiles>O=c1[nH]cnc2c1NNC=N2</smiles><smiles></smiles>

III<smiles></smiles>

VII

$\mathbf{V}$<smiles></smiles><smiles></smiles>

XI

$\mathbf{X}$<smiles>Oc1cnc(O)c2[nH]cnc12</smiles>

IV

VIII<smiles></smiles>

XII

Fig 2. Schemes of hypoxanthine molecular and zwitterionic tautomers

VI, IX, XV, XVIII, XIX, XXII molecular tautomers as well as the XXVII and XXIX zwitterion-tautomers, respectively (fig. 1 and 2). They are formed from the low energy tautomer-prototypes through rotation of hydroxylic groups by $180^{\circ}$ round the ordinary bonds $\mathrm{C}-\mathrm{O}$. The barriers of these rotations are within the range about $4.5-7 \mathrm{kcal} / \mathrm{mol}$; as it has been shown by calculation of rotamerization reaction coordinates, the saddle points correspond to the pairs of mirrorsymmetrical transitional states of rotamerization with orthogonal orientation of hydroxylic group relative to the ring plane (symmetry $C_{1}$ ) and considerably nonplanar geometry of the latter. In the case of other Xan tautomers with one or two hydroxylic groups the transitional state of rotamerization, as evidenced by the calculation of reaction coordinates, is the planar symmetrical one (symmetry $\mathrm{C}_{s}$ ). It is realized through the rotation of hydroxylic group on $180^{\circ}$ around the ordinary bonds $\mathrm{C}-\mathrm{O}$, the barriers of these rotations being within the range $5-9 \mathrm{kcal} / \mathrm{mol}$.

In most cases of Xan molecular tautomers the energetically preferable orientation of hydroxylic group is the cis-position, when it shades the adjacent double bond $\mathrm{C}=\mathrm{N}$ or $\mathrm{C}=\mathrm{C}$ (fig. 1); the same situation is observed for the molecular tautomers of the canonic nucleotide bases [6, 7 ] with some exceptions. Apparently, the interaction of hydroxylic groups with $\pi$-electron system of the adjacent double bond is 
Table I

Some calculated physico-chemical characteristics of the xanthine molecular and zwitterionic tautomers*

\begin{tabular}{|c|c|c|c|c|c|c|}
\hline \multirow{2}{*}{ Tautomer } & \multirow{2}{*}{$\begin{array}{l}\text { Formation heat, } \\
\text { kcal/mol (our result) }\end{array}$} & \multicolumn{2}{|c|}{ Relative energy. $\mathrm{kcal} / \mathrm{mol}$} & \multicolumn{2}{|c|}{ Dipole monesi, D } & \multirow{2}{*}{$\begin{array}{l}\text { looization potentual, } \\
\text { eV (our results) }\end{array}$} \\
\hline & & Our results & {$[21]^{* *}$} & Our results & {$[21]^{*}$} & \\
\hline $\mathbf{I}$ & -8.62 & 0 & 0 & 3.97 & 3.94 & 9.34 \\
\hline II & -4.43 & 4.19 & 9.11 & 6.63 & 6.86 & 9.27 \\
\hline III & 2.33 & 10.95 & 10.93 & 5.55 & 5.99 & 8.96 \\
\hline IV & 3.47 & 12.09 & 10.13 & 1.04 & 0.95 & 9.09 \\
\hline V & 5.34 & 13.96 & 17.23 & 6.46 & 6.37 & 9.15 \\
\hline VI & 7.26 & 15.88 & 22.88 & 5.70 & 5.90 & 9.14 \\
\hline VII & 7.55 & 16.17 & - & 5.02 & - & 8.92 \\
\hline VIII & 9.05 & 17.67 & - & 3.01 & - & 9.19 \\
\hline IX & 9.50 & 18.12 & - & 1.03 & - & 9.21 \\
\hline $\mathrm{X}$ & 9.53 & 18.15 & - & 8.05 & - & 9.25 \\
\hline XI & 9.58 & 18.20 & 14.43 & 3.49 & 3.55 & 9.23 \\
\hline XII & 10.51 & 19.13 & - & 2.42 & - & 9.29 \\
\hline XIII & 10.71 & 19.33 & - & 3.40 & - & 9.33 \\
\hline XIV & 11.52 & 20.14 & - & 5.42 & - & 9.35 \\
\hline $\mathrm{XV}$ & 12.10 & 20.72 & 16.91 & 4.31 & 4.31 & 9.29 \\
\hline XVI & 12.93 & 21.55 & - & 5.87 & - & 9.28 \\
\hline XVII & 16.02 & 24.64 & - & 8.72 & - & 9.09 \\
\hline XVIII, XIX & 18.12 & 26.74 & - & 8.18 & - & 9.18 \\
\hline$X X, X X I$ & 18.50 & 27.12 & 一 & 8.13 & - & 8.91 \\
\hline XXII & 20.26 & 28.88 & - & 9.36 & - & 9.19 \\
\hline XXIII & 20.67 & 29.29 & - & 5.70 & - & 9.06 \\
\hline XXIV & 24.06 & 32.68 & $\rightarrow$ & 4.91 & - & 9.24 \\
\hline XXV & 9.62 & 18.24 & - & 2.88 & - & 9.32 \\
\hline XXVI & 13.89 & 22.51 & - & 10.37 & - & 8.64 \\
\hline XXVII & 28.68 & 37.30 & - & 9.36 & - & 8.60 \\
\hline XXVIII & 30.04 & 38.66 & - & 11.17 & - & 8.63 \\
\hline XXIX & 30.73 & 39.35 & - & 9.63 & - & 8.46 \\
\hline $\mathbf{X X X}$ & 31.27 & 39.89 & - & 9.87 & - & 8.45 \\
\hline XXXI & 33.70 & 42.32 & - & 12.11 & - & 8.36 \\
\hline XXXII & 34.16 & 42.78 & - & 14.81 & - & 9.03 \\
\hline
\end{tabular}

*Total energy of the I molecular tautomer with fixed nuclei is equal to $49875.9 \mathrm{kcal} / \mathrm{mol}$; **ab initio data.

decisive for its cis-orientation. In the separate cases of trans-orientation of $\mathrm{OH}$ group the main role is probably played by an intramolecular hydrogen bond O-H....

It should be emphasized that exactly the cisorientation of hydroxylic group about the adjacent double bond $\mathrm{C} 2=\mathrm{N} 3$ is typical for the molecular tautomer III (fig. 1), which coincides with the results [21 1. So, the explanation of elementary mechanisms of point mutations (caused by guanine deamination) based on molecular configuration of Xan III with hydroxyl trans-orientation [2], which is the high 
Table 2

Structural parameters of the I and II xanthine molecular tautomers, its zwitterion XXVI and ylidic from XXV*

\begin{tabular}{|c|c|c|c|c|}
\hline Vatence bond/angle & ! & II & $x x v$ & $\mathrm{XXV} \mathbf{1}$ \\
\hline $\mathrm{C2O} 2$ & 1.249 & 1.249 & 1.248 & 1.247 \\
\hline $\mathrm{N} 1 \mathrm{C} 2$ & 1.409 & 1.400 & 1.404 & 1.433 \\
\hline C2N3 & 1.410 & 1.418 & 1.417 & 1.419 \\
\hline N1HI & 1.998 & 0.999 & 0.998 & 0.997 \\
\hline N1C6 & 1.405 & 1.416 & 1.411 & 1.394 \\
\hline C606 & 1.242 & 1.237 & 1.241 & 1.247 \\
\hline $\mathrm{C} 5 \mathrm{C} 6$ & 1.452 & 1.458 & 1.451 & 1.453 \\
\hline C5N7 & 1.394 & 1.396 & 1.410 & 1.389 \\
\hline $\mathbf{N} 3 \mathbf{C} 4 \mathbf{j}$ & 1.382 & 1.380 & 1.380 & 1.329 \\
\hline C4N9 & 1.404 & 1.395 & 1.409 & 1.422 \\
\hline N7C8 & 1.391 & 1.344 & 1.374 & 1.361 \\
\hline C8H8 & 1.098 & 1.096 & $\rightarrow$ & 1.098 \\
\hline N7H7 & 0.988 & - & 0.988 & 0.994 \\
\hline N3H3 & 0.959 & 0.993 & 0.993 & - \\
\hline N9H9 & 一 & 0.985 & 0.986 & 0.989 \\
\hline $\mathrm{N} 1 \mathrm{C} 2 \mathrm{O} 2$ & 120.4 & 121.9 & 121.4 & 116.2 \\
\hline$O 2 \mathrm{C} 2 \mathrm{~N} 3$ & 119.5 & 118.4 & 118.8 & 121.7 \\
\hline H1N1C2 & 116.5 & 116.3 & 116.5 & 117.4 \\
\hline C2N1C6 & 124.5 & 125.1 & 124.5 & 124.3 \\
\hline N1C606 & 120.6 & 118.6 & 119.9 & 122.5 \\
\hline N1C605 & 113.6 & 114.2 & 113.9 & 113.3 \\
\hline C6C5N7 & 131.3 & 130.0 & 131.4 & 131.9 \\
\hline $\mathrm{C} 2 \mathrm{~N} 3 \mathrm{C} 4$ & 118.9 & 117.9 & 118.3 & 114.4 \\
\hline C5C4N9 & 109.8 & 106.4 & 106.8 & 104.7 \\
\hline C5N7C8 & 106.3 & 105.3 & 109.8 & 108.4 \\
\hline N7C8H8 & 122.7 & 125.8 & - & 125.6 \\
\hline C5N7H7 & 125.2 & - & 123.2 & 124.7 \\
\hline C2N3H3 & 119.0 & 118.6 & 118.6 & - \\
\hline C4N9H9 & - & 127.3 & 125.5 & 126.0 \\
\hline
\end{tabular}

*Lengths of the valence bonds are given in $\AA$ and valence angles - in degrees.

energy transitional state of tautomer III rotamerization (its energy is over $5.95 \mathrm{kcal} / \mathrm{mol}$ than molecular tautomer III), is incompetent.

Molecular and zwitterionic tautomers of Xan are quasi-rigid structures, which is evidenced by the existence of low frequency $\left(\nu<150 \mathrm{~cm}^{-1}\right)$ fundamental vibrations in their calculated spectra. For example, the frequencies of non-planar vibrations of «butterfly» type (bend of purine ring along the $\mathrm{C} 4=\mathrm{C} 5$ bond) for the energetically preferable molecular tautomers I and II, as well as for the main tautomer-zwitterion XXVI are equal to 98,91 and $110 \mathrm{~cm}^{-1}$, accordingly (the non-scaled values of calculated frequencies are given).

The obtained results evidence (fig. 1 and table 1) that prototropic tautomerism of $\mathrm{Xan}$ in free state is caused, as a rule, by tautomerism of its imidazole ring. The main and practically single tautomer of Xan in isolated state $(\approx 99.9 \%)$ is molecular diketo form 
KONDRATYUK I. V. ET AL

Table 3

Atomic charges (e) and electronic densities (in arbitrary units) of the I and $I I$ xanthine molecular tautomers, its zwirtterion XXVI and ylidic from $X X V$

\begin{tabular}{|c|c|c|c|c|c|c|c|c|}
\hline \multirow{2}{*}{ Atom } & \multicolumn{2}{|c|}{1} & \multicolumn{2}{|c|}{ II } & \multicolumn{2}{|c|}{$\mathrm{XXV}$} & \multicolumn{2}{|c|}{$x \times V I$} \\
\hline & Charge & Density & Charge & Density & Charge & De.osity & Churge & Densily \\
\hline N1 & -0.362 & 5.362 & -0.372 & 5.372 & -0.363 & 5.363 & -0.385 & 5.385 \\
\hline $\mathrm{C} 2$ & 0.407 & 3.593 & 0.414 & 3.586 & 0.410 & 3.590 & 0.361 & 3.639 \\
\hline 02 & -0.358 & 6.358 & -0.358 & 6.358 & -0.353 & 6.353 & -0.337 & 6.337 \\
\hline N3 & -0.281 & 5.281 & -0.306 & 5.306 & -0.299 & 5.299 & -0.279 & 5.279 \\
\hline C4 & 0.080 & 3.920 & 0.089 & 3.911 & 0.100 & 3.900 & 0.176 & 3.824 \\
\hline C5 & -0.244 & 4.244 & -0.226 & 4.226 & -0.246 & 4.246 & -0.346 & 4.346 \\
\hline C6 & 0.400 & 3.600 & 0.405 & 3.595 & 0.399 & 3.601 & 0.400 & 3.600 \\
\hline 06 & -0.341 & $6.34 !$ & -0.299 & 6.299 & -0.300 & 6.330 & -0.382 & 6.382 \\
\hline N7 & -0.153 & 5.153 & -0.042 & 5.042 & -0.193 & 5.193 & -0.033 & 5.033 \\
\hline C8 & -0.036 & 4.036 & -0.097 & 4.097 & 0.037 & 3.963 & -0.028 & 4.028 \\
\hline N9 & -0.159 & 5.159 & -0.224 & 5.224 & -0.254 & 5.254 & -0.209 & 5.209 \\
\hline Hl & 0.273 & 0.727 & 0.272 & 0.728 & 0.275 & 0.725 & 0.256 & 0.744 \\
\hline H3 & 0.283 & 0.717 & 0.269 & 0.731 & 0.274 & 0.726 & - & - \\
\hline H7 & 0.279 & 0.721 & 一 & - & 0.279 & 0.721 & 0.294 & 0.706 \\
\hline H8 & 0.211 & 0.789 & 0.211 & 0.789 & - & - & 0.224 & 0.776 \\
\hline H9 & - & - & 0.264 & 0.736 & 0.265 & 0.735 & 0.289 & 0.711 \\
\hline
\end{tabular}

Table 4

Deprotonation energies of xanthine protons (in $\mathrm{kcal} / \mathrm{mol}$ ) and proton shifts in the ${ }^{1} \mathrm{H} N \mathrm{NR}$ spectra of the $10 \mathrm{mM}$ solution in DMSO-d6 of xanthine and its methyl derivatives (in the ppm from $T M S$ )*

\begin{tabular}{|c|c|c|c|c|}
\hline Compound & NIH & N3H & $\mathrm{N7H} / \mathrm{N} 9 \mathrm{H}$ & $\mathrm{C} 8 \mathrm{H}$ \\
\hline \multirow[t]{2}{*}{ Xan } & 10.820 & 11.530 & 13.260 & 7.925 \\
\hline & $(340.2 / 341.6)^{*}$ & $(335.0 / 325.1)$ & $(325.2 / 321)$ & $(357.8 / 352.2)$ \\
\hline$m^{9} \mathrm{Xan}$ & 10.750 & 11.920 & - & 7.610 \\
\hline$m^{3} \mathrm{Xan}$ & 11.900 & - & 13.490 & 8.010 \\
\hline
\end{tabular}

*In brackets are given calculated energies of deprotonation for the $\mathrm{N7H}$ (I) and $\mathrm{N9H}$ (II) $\mathrm{Xan}$ tautomers $\left(\mathrm{E}_{\mathrm{NH}} / \mathrm{E}_{\mathrm{N} 9 \mathrm{H}}\right.$ ) from [34]

I with the localization of imidazole ring imino proton at the N7 atom (tables 2,3 ), which agrees with the results of the work $[21]$, where four $\mathrm{N} 7 \mathrm{H}$ and $\mathrm{N9H}$ tautomers of Xan were investigated by the $a b$ initio LCAO-MO method at high approximations. We note that the concentration of the main tautomer-zwitterion
XXVI (the most energetically preferable one from the family of Xan tautomer-zwitterions) with imino proton localization at the N1, N3 and N9 atoms is practically zero $\left(\approx 3.4 \cdot 10^{-15} \%\right)$ in free state at room temperature.

It is obvious that the main molecular tautomer I 
as compared to tautomer II with higher energy has weaker both proton donor and proton acceptor properties of imidazole ring (table 3).

The transition of Xan from the isolated state to solution with universal mechanism of solvatation («inert» solvent) doesn't practically change the character of tautomer equilibrium. In fact, even under $\varepsilon>$ $>1$ the energy gap between tautomers II (N9H) and I $(\mathrm{N} 7 \mathrm{H})$ in solution, the value of which in free state with regard to zero vibrational energy $(66.28$ and $66.02 \mathrm{kcal} / \mathrm{mol}$ for tautomers I and II, correspondingly) measures $\Delta E=E_{\mathrm{l}}-E_{\mathrm{l}}=3.94 \mathrm{kcal} / \mathrm{mol}$, decreases, as estimation indicates accordingly to Onzager model by the following formula:

$$
\Delta E=\left(\frac{\mu_{l I}^{2}}{a_{l}^{2}}-\frac{\mu_{l}^{2}}{a_{l}^{2}}\right) \frac{\varepsilon-1}{2 \varepsilon+1}
$$

( $\varepsilon$ - dielectrical permeability of the solvent; $a_{1}, a_{n}$ radii of Onzager's spherical cavities for tautomers I and II, correspondingly $\left(a_{I} \approx a_{\mathrm{II}}=4.7 \AA\right) ; \mu_{\mathrm{I}}, \mu_{\mathrm{II}}$ corresponding dipole moments of tautomers I and II (table 1)), compared to free state only by $\Delta E==1.96$ $\mathrm{kcal} / \mathrm{mol}$. This fact as well as results [21] evidences insignificant population of tautomeric state II of molecular Xan in «inert» solvent at room temperature. The concentration of tautomer-zwitterion XXVI under the same conditions is too low $\left(\approx 1.6 \cdot 10^{-10} \%\right)$ to be taken into consideration. The energy gap $E_{\mathrm{xxv}}-E_{\mathrm{I}}$ under transition from gase phase into the «inert» solvent decreases with the same formula $\left(a_{\mathrm{Xxyl}}=\right.$ $=4.7 \AA$ ) by $\Delta E=6.36 \mathrm{kcal} / \mathrm{mol}$ and reaches $16.02 \mathrm{kcal} / \mathrm{mol}$ with regard to the zero vibrational energy $(66.15 \mathrm{kcal} / \mathrm{mol})$.

Based on the results of UV study [33] the conclusion was made that in water solutions Xan exists mainly as the $\mathrm{N} 7 \mathrm{H}$ tautomer. The analysis of chemical shifts values of the $\mathrm{N} 1 \mathrm{H}, \mathrm{N} 3 \mathrm{H}, \mathrm{N} 9 \mathrm{H} / \mathrm{N} 7 \mathrm{H}$ and $\mathrm{C} 8 \mathrm{H}$ protons in ' $\mathrm{H}$ NMR spectra of $\mathrm{Xan}, \mathrm{m}^{9} \mathrm{Xan}$ and $\mathrm{m}^{3} \mathrm{X}$ an and the comparison them with calculated [34 ] values of the deprotonation energy of the relative Xan protons for the $\mathrm{N} 7 \mathrm{H}$ and $\mathrm{N} 9 \mathrm{H}$ tautomers (table 4) give evidence in favour of the $\mathrm{N} 7 \mathrm{H}$ tautomeric form of Xan and $\mathrm{m}^{3} \mathrm{Xan}$ in DMSO. But it should be taken into consideration that interactions with amino acid residues in active sites of enzymes may induce transition to the N9H tautomeric form. For example, deprotonated carboxylic groups of aspartic and glutamic acids can obviously form complex with Xan via two cooperative hydrogen bonds involving adjacent protons at the $\mathrm{N} 3$ and $\mathrm{N} 9$ nitrogen atoms $[29,30]$

The analysis of electronic characteristics of Xan molecular-zwitterionic tautomers (tables 1,3 ) points to the essential distinctions in their reactivity, par- ticularly their proton donor and acceptor properties. The most considerable changes in charges at atoms and appropriate electron densities, as well the first potentials of ionization are therewith observed during transition from molecular to zwitterion form. The character of these changes indicates the greater reactvity of zwitterionic forms of Xan than molecular ones.

Among the zwitterionic tautomers the most attention should be paid to the ylidic form in which imino protons are localized at the N1, N3, N7 and N9 atoms and the $\mathrm{C} 8 \mathrm{H}$ proton is absent. The molecularkinetic mechanism of hydrogen-tritium exchange of $\mathrm{C} 8 \mathrm{H}$ group of $\mathrm{Xan}$ with water at acidic and neutral $\mathrm{pH}$ values is considered to be associated with the ylidic form [35]. Our results may be regarded as the conformation of the ylidic mechanisms of $H \leftrightarrow T$ exchange. In fact, the XXV Xan ylidic form in free state is the main one, $i$. e. energetically the most favorable form among the family of ylidic tautomers, and it is characterized by high proton affinity of the $\mathrm{C} 8$ atom $(226.9 \mathrm{kcal} / \mathrm{mol})$, exceeding its affinity in Xan molecular form II with proton of the N7 atom. The energy barrier of the XXV ylidic form formation from the molecular one in vacuum with participation of free proton $(18.2 \mathrm{kcal} / \mathrm{mol})$ agrees with experimental energy of activation of hydrogen-tritium exchange in the $\mathrm{C} 8 \mathrm{H}$ group of Xan $(21 \pm 1 \mathrm{kcal} / \mathrm{mol}[33 \mathrm{]})$ in water solution at acidic and neutral pHs. In essence, the main ylidic form XXV is properly the transitional state of $\mathrm{H} \leftrightarrow \mathrm{T}$ exchange reaction in the $\mathrm{C} 8 \mathrm{H}$ group of isolated Xan.

Hypoxanthine. By calculation results, the tautomeric molecular-zwitterionic family of Hyp, occuping the energy range about $26 \mathrm{kcal} / \mathrm{mol}$, consists of 12 structural isomers - 10 molecular (I-VII, IX-XI) and 2 zwitterions (XII, XIII) (fig. 2 and table 5). The other part of the total of 14 possible ones (E7t and E1c from [30]) are planar symmetrical transitional states of hydroxyl group rotation around the ordinary $\mathrm{C}-\mathrm{O}$ bond in the $\mathrm{V}$ and $\mathrm{XI}$ enolic molecular tautomers with the barriers of internal rotation $\approx 9.6 \mathrm{kcal} / \mathrm{mol}$. All without exception tautomers of $\mathrm{Hyp}$ are the planar symmetrical (symmetry $\mathrm{C}_{s}$ ) and dipole stable structures: atom deviations from planarity $\left(<7.5 \cdot 10^{-4} \AA\right)$ are much less than amplitude of out-of-plane vibrations. This coincides with the data [30].

The IV and $X$ enolic molecular tautomers are the high energy rotamers of the III and IX molecular tautomers, correspondingly: they are formed from the low energy tautomers on account of rotation of hydroxylic group by $180^{\circ}$ around the ordinary bond $\mathrm{C}-\mathrm{O}$. In this case the saddle points correspond to the pairs of mirror-symmetrical transitional states with 
KONDRATYUK I. V. ET AL.

Table 5

Some calculated physico-chemical characteristics of the hypoxanthine molecular and zwitterionic tautomers*

\begin{tabular}{|c|c|c|c|c|c|c|c|c|c|}
\hline \multirow{2}{*}{ Tautomer } & \multirow{2}{*}{$\begin{array}{l}\text { Formation } \\
\text { heat, kcat/mol } \\
\text { (our results) }\end{array}$} & \multicolumn{4}{|c|}{ Relative energy, kcal/mol } & \multicolumn{2}{|c|}{ Dipole monient, D } & \multicolumn{2}{|c|}{ lonization potential, eV } \\
\hline & & Our results & $\mid 31\}^{* *}$ & {$[31]^{\bullet * *}$} & $\{30\}^{* * *}$ & Our results & {$[30]^{* 4 *}$} & Our resulis & {$[30]^{* * *}$} \\
\hline 1 & 43.10 & -0.94 & 0.90 & 0.80 & 0.84 & 4.86 & 5.19 & 9.04 & 8.55 \\
\hline II & 44.04 & 0 & 0 & 0 & 0 & 1.72 & 1.80 & 9.21 & 8.73 \\
\hline III & 46.94 & 2.90 & 1.90 & 2.80 & 5.92 & 2.41 & 2.52 & 9.40 & 8.88 \\
\hline IV & 48.50 & 4.46 & 3.10 & 4.30 & 7.17 & 4.38 & 4.77 & 9.53 & 8.97 \\
\hline V & 49.31 & 5.27 & 4.20 & 5.70 & 8.31 & 4.62 & 5.16 & 9.53 & 9.05 \\
\hline VI & 50.15 & 6.11 & 7.20 & 6.70 & 7.65 & 4.00 & 3.92 & 9.09 & 8.66 \\
\hline VII & 57.06 & 13.02 & 21.10 & 20.20 & 21.29 & 9.78 & - & 8.98 & - \\
\hline VIII & 57.58 & 13.54 & - & - & - & 3.53 & - & 9.14 & - \\
\hline IX & 60.76 & 16.72 & - & - & 14.22 & 3.55 & - & 9.28 & - \\
\hline $\mathbf{X}$ & 60.87 & 16.83 & - & - & 15.53 & 5.62 & - & 9.14 & - \\
\hline XI & 63.44 & 19.4 & - & 一 & 20.48 & 6.07 & - & 9.30 & - \\
\hline XII & 67.74 & 23.70 & - & - & 23.04 & 9.84 & - & 8.46 & - \\
\hline XIII & 68.99 & 24.95 & - & - & 19.29 & 9.72 & - & 8.45 & - \\
\hline
\end{tabular}

*Total energy of the I molecular tautomer with fixed nuclei is equal to $42475.1 \mathrm{kcal} / \mathrm{mol} ;{ }^{* *} a b$ initio data; ***DFT data.

orthogonal orientation of hydroxylic group against the purine ring «plane» (symmetry $C_{1}$ ) and significantly non-planar geometry of the latter. It takes notice of the fact that the energetically favourable orientation of hydroxylic group is cis-position, when it «shades» the adjacent double bond $\mathrm{C} 6=\mathrm{N} 1$ or $\mathrm{C} 5=\mathrm{C} 6$ (fig. 2 and table 6 ). The same situation takes place in the case of molecular tautomers of canonical nucleotide bases $[6,7]$ with rare exceptions. Obviously, it is the general case that in enolic molecular tautomers of nucleotide bases the interaction of hydroxylic group with $\pi$-electron system of the adjacent double bond is decisive for its cis-orientation.

The Hyp tautomers are quasi-rigid structures, which is evidenced by the presence of low frequency $\left(<150 \mathrm{~cm}^{-1}\right.$ ) fundamental vibrations in their calculated spectra. Thus, for example, the frequencies of the lowest energy planar vibrations of «butterfly» type (bend of purine ring along the $\mathrm{C} 4-\mathrm{C} 5$ bond) for the most energetically favourable tautomers I $(\mathrm{N} 9 \mathrm{H})$ and II $(\mathrm{N} 7 \mathrm{H})$ measure 134 and $145 \mathrm{~cm}^{-1}$, correspondingly (the non-scaled values of calculated frequencies are given).

In accordance with data $[30,31]$, results obtained (fig. 2, table 5) give evidence that prototropic tautomerism of Hyp, as in the case of Xan is mainly caused by the tautomerism of its imidazolic ring. The stability order of Hyp tantomers agrees with the $a b$ initio data [31], except the most stable I and II Hyp tautomers. The AMI method overestimates the I tautomer stabiliity. The $a b$ initio calculations predict a slight energetics advantage $(0.8-0.9 \mathrm{kcal} / \mathrm{mol})$ of the II tautomer. However, tautomer relative cnergy deviations between our results and $a b$ initio calculation [31] do not exceed such deviations between the [30] and [31] data. Furthermore, our dipole moment values for Hyp tautomers and analogical values for six most stable Hyp tautomers from [31] are rather close. The latter is also true for a first ionizations potentials which should be regarded as upper limits of experimental values [23]. It is noteworthy that the ground state tautomer of Hyp is the least polar (its dipole moment is equal to $1.72 \mathrm{D}$ (table 5)).

In isolated state at room temperature two energetically favourable ketonic tautomers $\mathrm{N} 7 \mathrm{H}$ (II) and $\mathrm{N} 9 \mathrm{H}$ (I) coexist, less polar form $\mathrm{N} 7 \mathrm{H}$ being the main one $(80 \%)$. Under the same conditions the concentration of the main enolic tautomer (III) measures only $0.15 \%$. This fact quantitatively confirms the conclusion about the character of Hyp tautomeric equilibrium in vacuum made on the bases of experimental investigation of its IR spectra in low tempe- 
Table 6

Structural parameters of the I and II hypoxanthine molecular tautomers, its zwitterion $X I I$ and ylidic from $V I I^{*}$

\begin{tabular}{|c|c|c|c|c|}
\hline Valence boud/angle & I & II & vIII & XII \\
\hline $\mathrm{C} 2 \mathrm{H}_{2}$ & 1.112 & 1.112 & 1.112 & 1.113 \\
\hline $\mathrm{N} 1 \mathrm{C} 2$ & 1.385 & 1.394 & 1.388 & 1.326 \\
\hline $\mathrm{C} 2 \mathrm{~N} 3$ & 1.323 & 1.318 & 1.323 & 1.387 \\
\hline $\mathrm{N} 1 \mathrm{H} 1$ & 0.996 & 0.995 & 0.996 & - \\
\hline N1C6 & 1.423 & 1.409 & 1.417 & 1.406 \\
\hline C606 & 1.238 & 1.244 & 1.242 & 1.245 \\
\hline $\mathrm{C} 4 \mathrm{C5}$ & 1.444 & 1.445 & 1.429 & 1.454 \\
\hline C5C6 & 1.456 & 1.453 & 1.449 & 1.472 \\
\hline C5N7 & 1.394 & 1.389 & 1.405 & 1.389 \\
\hline N3C4 & 1.393 & 1.396 & 1.391 & 1.347 \\
\hline C4N9 & 1.393 & 1.404 & 1.408 & 1.417 \\
\hline N7C 8 & 1.349 & 1.397 & 1.381 & 1.364 \\
\hline $\mathrm{C8H8}$ & 1.096 & 1.097 & - & 1.097 \\
\hline N7H7 & - & 0.987 & 0.988 & 0.994 \\
\hline N9H9 & 0.986 & - & 0.987 & 0.989 \\
\hline $\mathrm{N} 1 \mathrm{C} 2 \mathrm{H} 2$ & 116.2 & 115.4 & 116.1 & 115.9 \\
\hline $\mathrm{H} 2 \mathrm{C} 2 \mathrm{~N} 3$ & 116.6 & 116.9 & 116.8 & 113.0 \\
\hline $\mathrm{H} 1 \mathrm{~N} 1 \mathrm{C} 2$ & 119.9 & 120.1 & 120.1 & 一 \\
\hline C2N1C6 & 122.1 & 121.5 & 121.6 & 119.5 \\
\hline N1C606 & 118.7 & 120.8 & 120.0 & 124.4 \\
\hline N1C6C5 & 113.3 & 112.7 & 113.0 & 114.4 \\
\hline C6C7N7 & 130.5 & 131.3 & 132.0 & 133.0 \\
\hline $\mathrm{C} 2 \mathrm{~N} 3 \mathrm{C} 4$ & 113.7 & 115.0 & 114.2 & 111.6 \\
\hline C5C4N9 & 105.8 & 109.1 & 106.2 & 105.5 \\
\hline C5N7C8 & 104.9 & 105.9 & 109.5 & 108.7 \\
\hline N7C8H8 & 125.3 & 122.2 & - & 125.7 \\
\hline C5N7H7 & - & 125.8 & 123.8 & 124.6 \\
\hline C4N9H9 & 126.4 & - & 124.6 & 126.2 \\
\hline
\end{tabular}

${ }^{*}$ Lengths of the valence bonds are given in $\AA$ and valence angles - in degrees.

rature matrix isolation $[26]$. It should be noted that in order to interpret the weak vibrational bands observed at significant accumulation of signals at the Hyp evaporation temperature $262{ }^{\circ} \mathrm{C}$ and assigned to enolic tautomers, in the first turn its rotamer IV (along with the main enolic tautomer III of Hyp) should be taken into consideration, but not the high energy rotomer $V$ (fig. 2, table 5), as done in [26].

The analysis of electron characteristics of Hyp molecular-zwitterionic tautomers (tables 5,7 ) points to the significant difference in their reaction ability, particularly proton donor and proton acceptor properties. The greatest changes of charges at atoms and correspondent electron densities, as well the most considerable deviations in the first potentials of ionization are observed under the transition from molecular to zwitterionic form. The character of these changes shows the greater reactivity of zwitterionic form of Hyp as compared to molecular ones.

The Hyp transition from the isolated state to 
KONDRATYUK I. V. ET Al

Table 7

Atomic charges (e) and electronic densities (in arbitrary units) of the I and II hypoxanthine molecular tautomers, its zwirtterion XII and ylidic from $V I I$

\begin{tabular}{|c|c|c|c|c|c|c|c|c|}
\hline \multirow{2}{*}{ Atom } & \multicolumn{2}{|c|}{1} & \multicolumn{2}{|c|}{ II } & \multicolumn{2}{|c|}{$x \times y$} & \multicolumn{2}{|c|}{$x \times v I$} \\
\hline & Charge & Density & Charge & Density & Charge & Density & Charge & Density \\
\hline N1 & -0.338 & 5.338 & -0.326 & 5.326 & -0.323 & 5.323 & -0.273 & 5.273 \\
\hline $\mathrm{C} 2$ & 0.075 & 3.925 & 0.047 & 3.953 & 0.064 & 3.936 & -0.053 & 3.947 \\
\hline N3 & -0.180 & 5.180 & -0.123 & 5.123 & -0.165 & 5.165 & -0.285 & 5.285 \\
\hline $\mathrm{C} 4$ & 0.016 & 3.984 & 0.007 & 3.993 & 0.029 & 3.971 & -0.117 & 3.883 \\
\hline $\mathrm{C} 5$ & -0.213 & 4.213 & -0.218 & 4.218 & -0.219 & 4.219 & -0.311 & 4.311 \\
\hline $\mathrm{C} 6$ & 0.382 & 3.618 & 0.371 & 3.629 & 0.368 & 3.632 & -0.338 & 3.662 \\
\hline 06 & -0.316 & 6.316 & -0.357 & 6.357 & -0.347 & 6.347 & -0.355 & 6.355 \\
\hline N7 & -0.063 & 5.063 & -0.165 & 5.165 & -0.201 & 5.201 & -0.045 & 5.045 \\
\hline $\mathrm{C} 8$ & -0.090 & 4.090 & -0.052 & 4.052 & 0.027 & 3.973 & -0.039 & 4.039 \\
\hline N9 & -0.191 & 5.191 & -0.108 & 5.108 & -0.226 & 5.226 & -0.188 & 5.188 \\
\hline $\mathrm{H} 1$ & 0.253 & 0.747 & 0.255 & 0.745 & 0.257 & 0.743 & - & - \\
\hline $\mathrm{H} 2$ & 0.186 & 0.814 & 0.188 & 0.812 & 0.190 & 0.810 & -0.184 & 0816. \\
\hline $\mathrm{H} 7$ & - . & - & 0.275 & 0.725 & 0.275 & 0.725 & -0.294 & 0.706 \\
\hline H8 & 0.207 & 0793. & 0.207 & 0.793 & - & - & -0.224 & 0.776 \\
\hline $\mathrm{H} 9$ & 0.270 & 0.730 & - . & - & 0271 & 0729. & -0.285 & 0.715 \\
\hline
\end{tabular}

Table 8

Chemical shifts in the ${ }^{1} H$ NMR spectra of hypoxanthine and deoxyinosine in the $10 \mathrm{mM}$ DMSO-do (in ppon from TMS)

\begin{tabular}{|c|c|c|c|c|}
\hline Compouod & NIH & $\mathrm{N} 9 \mathrm{H} / \mathrm{N} 7 \mathrm{H}$ & $\mathrm{C2H}$ & $\mathrm{C} 8 \mathrm{H}$ \\
\hline Hyp & 12.230 & 13.300 & 8.115 & 7.971 \\
\hline dI & 12.340 & - & 8.310 & 8.063 \\
\hline
\end{tabular}

solvent with the universal mechanism of solvatation shifts completely the $\mathrm{N} 7 \mathrm{H} \leftrightarrow \mathrm{N} 9 \mathrm{H}$ tautomeric equilibrium to the more polar tautomer I $(80 \%$ at the room temperature). Really, the energy gap between the I and II tautomers in the solvent with $\varepsilon>1$ increases (valued as in the case of Xan; $a_{1} \approx a_{\mathrm{II}}=4.5$ $\AA ; \mu_{1}, \mu_{\mathrm{II}}-$ as in table 6 ) compared to vacuum by $\Delta E=1.63 \mathrm{kcal} / \mathrm{mol}$ and reaches $0.83 \mathrm{kcal} / \mathrm{mol}$. The concentrations of all other tautomers with except of the II tautomer $(14.1 \%)$ under the same conditions are too small for consideration.

According to the results of UV spectroscopic investigations [33], neutral molecule of Hyp exists mainly as the N9H tautomer in water solution. Closed values of chemical shifts of the $\mathrm{NIH}, \mathrm{C} 2 \mathrm{H}$ and $\mathrm{C} 8 \mathrm{H}$ protons in the 'H NMR spectra of the Hyp and $\mathrm{dI}$ solutions in DMSO points out to prevalence of the $\mathrm{N9H}$ tautomer in DMSO as well (table 8).

Thus, in conditions similiar to physiological ones the content of Hyp enolic form compared to content of guanine enolic form $[6,7,15]$ may be neglected as the value of Hyp enolic form is smaller than guanine enolic form by one and half order. So, the suggestion [26] on exactly this reason, favouring the decrease of possibility of formation mismatched pairs Hyp:Ura and thereby possible mistakes of codon-anticodon 
recognition, of substitution of guanine to Hyp in anticodon triplets of tRNAs is absolutely reasonable.

As in the case of Xan, exactly the VIII ylidic form in free state is the main one, $i$. e. the most energetically favorable among the zwitterionic tautomers family. It is characterized by the high proton affinity of the $\mathrm{C} 8$ atom $(232.77 \mathrm{kcal} / \mathrm{mol})$, the energy barrier of reaction of ylidic form VIII formation from molecular tautomer I in vacuum with the free proton participation $(14.48 \mathrm{kcal} / \mathrm{mol})$ conforming to experimental energy of hydrogen-tritium exchange activation in the C8H group of Hyp $(21 \pm 1 \mathrm{kcal} / \mathrm{mol}$ [33] in water solution under acidic and neutral pHs. The main ylidic form VIII is in fact the transition state of reaction $\mathrm{H} \leftrightarrow \mathrm{T}$ exchange in the $\mathrm{C} 8 \mathrm{H}$ group of Hyp in isolated state.

Concluding remarks. All the conceivable molecular and zwitterionic tautomers of the minor nucleotide bases Xan and Hyp were investigated by the semi-empirical quantum-chemical AM1 method with full optimization of all the parameters. Geometric and electronic structures and energetic features of their complete molecular-zwitterionic families of tautomers were determined. It should be emphasized that the $X$ an and Hyp prototropic tautomerism comprises all their protons including so-called carboprotons, i. e. the protons bound to the carbon atoms.

In this case the AM1 method appears to be quite relevant for estimation of tautomer physico-chemical features which are biologically significant.

One of the consequences of tautomer formation may be significant non-planarity of some of them. So, in spite of planarity of the molecule of Xan in the ground state and most of its tautomers, some enolic tautomers of Xan were proved to be essentially non-planar because of the hindrance of hydroxyl groups with two adjacent imino groups. In the case of one neighboring imino group, due to steric conflict between hydroxyl and imino protons, enolic tautomers of Xan and Hyp with cis-orientation of hydroxyl group to adjacent imino group can not be considered as stable structures but as transition states of hydroxyl group internal rotation. Exactly because of that reason energetic disadvantage of the E7t and E1c enolic «tautomers» from [30] relative to the E7c and Elt tautomers are as high as 8.83 and $10.65 \mathrm{kcal} / \mathrm{mol}$ respectively, which are close to the barriers of hydro$\mathrm{xyl}$ rotations $(\approx 9.6 \mathrm{kcal} / \mathrm{mol})$.

So then, it is a steric hindrance in enolic tautomers that reduces the numbers of molecular-zwitterionic tautomers in comparison with prediction of qualitative stereochemical analysis. Apropos, energetically favourable orientation of hydroxylic group is a cis-position to the adjacent double bound. It seems to be typical for oxopurine tautomers of nucleotide bases. Thus, prototropic tautomerism of Xan and Hyp is mainly attached to the imidazolic part of purine ring. This type of tautomerism in purinic bases is essentially affected by the nature of pyrimidinic rest. The $\mathrm{N} 9 \mathrm{H} \leftrightarrow \mathrm{N} 7 \mathrm{H}$ tautomerism prevails in Hyp $[30$, $31]$, Pur $[9,10]$, Ade [6-10], Xan $[18,19,21]$, but in the case of Gua main tautomeric events take place in pyrimidinic ring $[6,7,11,13,15,26]$.

The evaluation of polar environmental influence carried out in the framework of classical Onzager model shows the shift of the $\mathrm{N9H} \leftrightarrow \mathrm{N} 7 \mathrm{H}$ equilibrium to the more polar N9H tautomer for both bases. For isolated and dissolved in anhydrous DMSO Xan the $\mathrm{N} 9 \mathrm{H} \leftrightarrow \mathrm{N} 7 \mathrm{H}$ equilibrium is strongly shifted to the diketonic - N7H tautomer. Unlike isolated state [30, $31 \mathrm{l}$, in anhydrous DMSO solution Hyp was shown to exist mostly as the keto-N9H tautomer with noticeable amount of the keto- N7H tautomer. It is noteworthy to mention that the N7H tautomers of purine nucleotide bases play a key role in synthesis of nucleic acids ( 136$]$ and refs. therein).

So, tautomeric equilibrium of Xan and Hyp may be disturbed by environment both via non-specific interactions determined by tautomer dipole moment and dielectric permeability of solvent at the first approximation and by Iocal specific interactions (e. g., with amino acid residues in the active sites of enzymes) derived from geometric and electronic complementarity of the partners. The authors believe that the latter is the leading factor in real biological systems. Molecular-zwitterionic families of tautomers are situated in the energetic range which is commensurable with the energy of a few H-bonds. High energy tautomers can be realized through expendient hydrogen bonding with amino acid residues of proteins, for example.

We mean that biological significance of nucleotide base tautomers could not be confined by their direct physico-chemical detection under thermodynamic equilibrium and homogenic environment. In other words, from biological point of view the most energetically favourable tautomers are merely «a top of iceberg». Such approach to the problem of tautomerism in nucleotide bases, in general, may cast a new light on the mechanisms of enzymatic catalysis, interconversions of the bases, their metabolism etc., though traditionaly the interest in tautomerism of nucleotide bases was confined only to its possible mutagenic effects.

Perceptibly greater polarity of zwitterionic tautomers determines their greater ability of participating in chemical reaction. In spite of their energetic disadvantage they may be formed in essentially 
non-equilibrium environment of living cell in the course of biochemical reactions. Besides, it is known that metal ions are able to stabilize them [37], and in the work [7] the stabilizing role of their interactions with proteins is discussed.

The most favourable ylidic tautomers formed with the participation of the $\mathrm{C} 8 \mathrm{H}$ carboprotons of tautomers among the zwitterionic families may be realized as an intermediates in the course of the $H \leftrightarrow T$ exchange between the $\mathrm{C} 8 \mathrm{H}$ proton of purine bases and water, which gives a support to the suggestion of its ylidic mechanism [35]. This mechanism should be taken into account under investigation of lethal and mutagenic effects of tritium incorporated into the purine 8 positions of DNA [38].

It should be emphasized that investigation of all the possible tautomeric forms is not «purely academic question», as it may seem at the first view. To understand the possible mechanisms of biochemical reactions and the participation of nucleotide bases in nucleic acid functioning, it is necessary to take into consideration not only the most favourable tautomers.

It is quite clear that all the tautomers with the excess of formation energy (with respect to the most favourable tautomer), which does not exceed the activation energy of biochemical reactions $(20-$ $30 \mathrm{kcal} / \mathrm{mol}$ ), should be regarded as possible participants in them. The authors believe that there is a large field to be investigated in this direction.

Finally, we would like to emphasize the growing significance of quantum-chemical investigation on nucleotide bases' prototropic tautomerism because their biologically important patterns are far not in every case experimentally detectable.

The complete numerical information is available in database of Department of Molecular Biophysics at the Institute of Molecular Biology and Genetics of the Ukrainian National Academy of Sciences. The work was sponsored by the Ukrainian State Committee on Science and Technology (Contract 5.4/77).

\section{I. В. Копдратюк, С. П. Самійленко, І. М. Коломісць, А. Л. Потягайло, Д. М. Говорун}

Прототропна молекулярно-цвітеріонна таутомерія ксантину та riпоксанину: неочікуване біологічне значенжя

Резюме

Напівемпіричним квантовомеханічним методом АMI досліджено прототропну таутомерію ксантину та гіпоксантину. Були встановлені гсометричні, енергетичні та іниі фізикохімічні харахтеристики їніх повних молскулярно-цвітеріонних сімейств таутомерів. Вплив оточения 3 універсальним механізмом сольватації на таутомерну різновасу оцінено в наблихенні Онзаzера. Зіставлення розрахунків з даними Н ЯМР свідить на користь таутомерів N7H ma N9H для ксантину та сіпоксантину відповідно в дМСО. Обговорю- сться мохлива біологічна роль маутомерних форм (особливо цвітеріонних) ксантину та гіпоксантину. Розелянуто стабілізуючий вплив оточення та спечиифінні взасмодї з білками на рідкісні таутомерні форми Обговорюсться біологічне значення високоенергетичних таутомерів.

И. В. Кондратюк, С. П. Самойленко, И. Н. Коломиец, A. Л. Нотягайло, Д. Н. Говорун

Прототропная молекулярно-цвиттерионная гаутомерия ксантина и гипоксантина: неожиданное биологическое значенис.

\section{Резюме}

Полуэмпирически квантовомеханическим методом АMI ис следована прототропная таутомерия ксантина и гипоксантина. Были установлень геомстрические, энергетические и другие физико-химические характеристики их полных молекулярно-цвиттерионных семейств паутомеров. Влияние окружения с универсальньм механизмом сольватации на таутомерное равновесие оценено в приближении Онзасера. Сопостав. ление расиетов с данными Н ЯМР сөидетельствует в пользу таутомеров $\mathrm{N7H}$ и $\mathrm{N9H}$ для ксантина и гипоксантина соответственно в ДМСО. Обсуждается возможная биологическая роль таутамерных форм (особенно цвитлерионных) ксанти на и сипоксантина. Рассмотрено стибилизирующее влияние окружения и специфические взаимодействия с белками на редкие таутомерные формы. Обсуждаенкя биологическље значение высокознергтических таутомерок.

\section{REFERENCES}

1. Shaburova Z. A., Bogdanov A. A. Chemistry of nucleic acids and their components.-M.: Chimiya, 1978.-582 s. (Russ.)

2. Poltev V. I., Bruskov V. I., Shulyupina N. V., Rein R., Shibata $M$., Ornstein $R .$, Miller $G$. Genotoxic damages of nucleic acid bases and their biological consequences. Review and perspectives of experimental and computational investigations // Molecularnaya Biologiya (Russ)._-1993.-27, N 4.-P. 734-757.

3. Saenger $W$. Principte of nucleic acid structure / Ed. C. R Cantor $/ /$ Advanced texts in chemistry.-New York etc: Springer, 1984

4. Rossi C., Picchi M. P., Tiezzi E., Corbini G., Corti $P$. Conformational and dynamic investigation in solution of inosine and its molecular complex, inosiplex by proton and carbon NMR spectroscopy // Magnetic resonance in chemistry.--New York: John Willey and Sons, 1990.-Vol. 28.-P. 348.

5. Mitsuya $H$., Broder $S$. Inhibition of the in vitro infectivity and cytoplasmic effect of human $\mathrm{T}$-lymphotrophic virus type III/lymphadenopathy-associated virus (HTLV-III/LAV) // Proc. Nat. Acad. Sci. USA. - 1986. -83, N 6.-P. $1911-$ 1915.

6. Norinder $U$. A theoretical reinvestigation of the nucleic bases adenine, guanine, cytosine, thymine and uracil using AM1// J. Mol. Struct. (Theochem.) -1987-151 - P. 259-269.

7. Sabio M., Topiol S., Lumma $W . C$., Jr. An investigation of tautomerism in adenine and guanine $/ / \mathrm{J}$. Phys. Chem.1990.-94, N 4.-P. 1366-1372.

8. Nowak M. J., Lapinski L., Kwiatkowski J. S., Leszczynski J. Molecular structure and infrared spectra of adenine. Experimental matrix isolation and density functional study of adenine $15 \mathrm{~N}$ isotopomers // 3. Phys. Chem. $-1996 .-100$. N 9.-P. 3527-3534.

9. Nowak M. J., Lapinski L., Kwiatkowski J. S. An infrared matrix isolation study of tautomerism in purine and adenine // Chem. Phys. letts. $-1989 .-157$, N 1/2.-P. 14-18. 
10. Nowak M. J., Rostowska H., Lapinski L., Kwiatkowski J. S. Leszczynski J. Tautomerism $\mathrm{N}(9) \mathrm{HN}(7) \mathrm{H}$ of purine, adenine, and 2-chloroadenine: combined experimental IR matrix isolation and ab initio quantum mechanical studies // J. Phys. Chem.-1994.-98, N 11.-.P. 2813-2816.

11. Szczesniak K, Szczesniak M., Person W. B. Infrared studies and the effect of ultraviolet irradiation on the tautomers of 9-methylguanine isolated in an argon matrix // Chem. Phys. Letts. -1988. - 153, N 1.-P. 39-44.

12. Kwiatkowski J. S., Person W. B.. The tautomerism of the nucleic acid bases revisited: from non-interacting to interacting bases // Theor. biochem. and Mol. Biophys. / Eds D. I. Beverige, R. Lovery.-New York: Adenine press, 1990.P. 153-171.

13. Szczesniak $K$, Szczesniak M. Matrix isolation infrared studies of nucleic acid constituents // J. Mol. Struct.-1987.-156, N 1/2,-.P. 29--42.

14. Brown R., Goadfrey P. D., McNuaghton D., Picrlot A. P. A study of the major gas-phase tautomer of adenine by microwave spectroscopy $/ / \mathrm{Chem}$. Phys. Letts. - 1989.-156, N 1.-P. $61-63$.

15. Leszczynski $J$. The potential energy surface of guanine is not flat: an $\alpha b$ initio study with large basis sets and higher order electron correlation contribution // J. Phys. Chem. A.1998. -102, N 13. - P. 2357-2362.

16. LeBreton P. R., Yang $X$, Urano $S$., Fretzer $S$. $Y u M$. Leonard N. J., Kumar $S$. Photoemission properties of methylsubstitited guanines: photoelectron and fluorescence investigation of 1,9-dimethylguanine, $\mathrm{O}^{6}, 9$-dimethy!guanine, and 9methylguanine // J. Amer. Chem. Soc. $-1990 .-112$, N 6.P. $2138-2145$.

17. Gould I. R., Vincent M. A., Hillier I. H., Lapinski L, Nowak $M$. J. A new theoretical prediction of the infrared spectra of cytosine tautomers // Spectrochim. acta. - 1992. -48A, N 6.P. $811-818$.

18. Cavalieri $I . F$., Fox J. J., Stone A., Chang $N$. On the nature of xanthine and substituted in solution // J. Amer. Chem. Soc. $-1954,-76$, N 4.-P. 1119-1122.

19. Lichtenberg D., Bergmann F., Neiman $Z$. Tautomeric forms and ionisation processes in xanthine and its $\mathrm{N}$-methyl derivalives // J. Chem. Soc. (C) -1971 . -N 9.-.P. 1676-1682.

20. Mizuno H., Fujiwara T., Tomita $K$. The crystal and molecular structure of the sodium salt of xanthine // Bull. Chem. Soc. Jap. - 1969. - 42, N 11._. . 3099-3105.

21. Sponer J., Leszczynski J. Tautomerism of xanthine: the second-order Moller-Plesset study // Struct. Chem.-1995.6, N 4/5. $\rightarrow$ P. $281-286$.

22. Bergmann F., Kleiner M., Neiman Z., Rashi $M$. The ionisation sequence of hypoxanthine and 6-mercaptopurine // Israel $\mathbf{J}$. Chem.-1964.-2, N 2.-P. 185-196.

23. Lin J., Yu S., Peng S., Akijama I., Li K, Le L. K., LeBreton $P$. $R$. Ultraviolet photoelectron studies of the ground-state electronic structure and gas-phase tautomerism of purine and adenine // J. Phys. Chem.-1980.-102, N 14.-.P. 46274631 .

24. Munns A. R. I., Tollin P. The crystal and molecular structure of inosine // Acta cryst.-1970.-B26, N 11.-P. 11011113.
25. Krishnan R., Seshadri T. P. Crystal structure of sodium deoxyinosine // Nucleosides and Nucleotides. 1992.-11, N 5.-P. 1047-1057.

26. Sheina G. C., Stepanian S. G., Radchenko E. D., Blagoi Yu. $P$. IR spectra of guanine and hypoxanthine isolated molecules // J. Mol. Struct.-1 987.-158, N 2.-P. 275-292.

27. Musui Q., Yuoxin J., Wenqin L., Junru B., Peijuan G., Renlong W., Keqin $Z$., Debuo $W$. Biological function of modified nucleotides in tRNA molecules - synthesis and biological activity of the analogues of yeast alanyl tRNA with I34 replaced by A34 or G34 // Scientia Sinica, Ser. B.1988.-31.-P. 695

28. Zheltovsky M. V., Samijlenko S. P., Kolomiets' I. M., Kondratyuk $I . V$., Stepanyugin $A$. V. Investigation of interactions of hypoxanthine, xanthine and its methyl- and glycosylderivatives with amino acid carboxylic group by spectroscopic methods // Biopolymery i Kletka (Ukr)._1993._-9, N 3.-P. 72-77.

29. Zheltovsky N. V., Samoilenko S. A., Kondratyuk I. V., Kolomicts 1. N., Stepunyugin $A$. $V$. Recognition of purine bases and nucleosides by the amino acid carboxylic group // $\mathrm{J}$. Mol. Struct. - 1995.-344, N 1.-P. 53-62.

30. Costas $M$. E., Acevedo-Chavez $R$. Density functional study of the neutral hypoxanthine tautomeric forms $/ / \mathrm{J}$. Phys. Chem.-1997.-A101, N 44.-P. 8309-8318.

31. Hernandes B., Luque F. J., Orozko M. Tautomerism of xanthine oxidase substrates hypoxanthine and allopurinol // $\mathrm{J}$. Org. Chem. - 1996.-61, N 17.-P. 5964-5971.

32. Samijlenko $S$. P., Kolomiets' I. M., Kondratyuk I. $V$., Stepanyugin $A$. $V$. Model considerations on physico-chemical nature of protein-nucleic acid contacts through amino acid carboxylic groups: spectroscopic data // Bioplymery i Kletka (Ukr).-1998.-14, N 1, - P. 47-53.

33. Morozov Ju. V., Bazhulina N. P. Electronic structure, spectroscopy and reactivity of the molecules.-Moscow: Mir, 1989.-288 p. (Russ.).

34. Hovorun D. M., Kondratyuk I. V., Zheltovsky M. V. Acidicbasic properties of molecular xanthine and its complex formation ability // Biopolymery i Kletka (Ukr).-1994.-10, N 6.-P. 61-63.

35. Maslova R. N., Lesnik E. A., Varshavsky Ya. M. Kinetics and mechanism of the $3 \mathrm{H} \rightarrow 1 \mathrm{H}$ exchange in $\mathrm{C}(8) \mathrm{H}$ groups of purine derivatives // Molekulyarnaya Biologiya (Russ) _- 1975. -9 , N 2.-P. 310-320.

36. Eads J. C., Scapin G., Xu Y., Grubmeyer C., Sacchettini J. $C$. The crystal structure of human hypoxanthine-guanine phosphoribosyltransferase with bound GMP // Cell.-1994.78, N 2.-P. $325 \div 334$.

37. Aoki K. Metal binding effects on nucleic acid structures // Comprehensive supramolecular chemistry / Eds J. L. Atwood, J. E. D. Davies, D. D MacNicol, F. Vogtle, J.-M. Lehn.-New York: Pergamon press, 1996.- Chapter 8.-P. 269-294.

38. Konevega $L V$., Kalinin $V . I$. Lethal and mutagenic action of tritium incorporated in the purine 8 positions of the phage $\lambda$ DNA and the Fpg protein role // Genetika (Russ)._1998.34, N 7.-P. 897--902. 